\title{
Simplified method for the rubella haemagglutination inhibition screening test
}

\author{
P. P. MORTIMER, SUSAN M. JORDAN, AND I. V. SMITH \\ From the Public Health Laboratory and Department of Microbiology, Central Middlesex Hospital, \\ Park Royal, London NW10 7NS
}

SUMMARY A modification of the rubella haemagglutination inhibition (HAI) test in which both pretreatment and serum titration are carried out in wells of the same microtitre plate saves time, labour, and materials and gives results comparable to a conventional HAI procedure.

Although over the last five years diagnostic laboratories have faced a growing demand for rubella HAI screening tests few attempts have been made to simplify the procedure. We have been looking for ways to reduce the number of manipulations required so that larger batches of sera may be handled. Our findings may be of interest.

\section{Materials}

The sera used were specimens sent for rubella haemagglutination inhibition (HAI) tests. A $25 \%$ kaolin suspension in borate buffer $\mathrm{pH} 9.0$ (Flow Laboratories) was diluted for use with an equal volume of borate buffer $\mathrm{pH} 9.0$, to give a $12.5 \%$ suspension. The diluent for the HAI procedure was dextrose gelatin veronal buffer with $0 \cdot 2 \%$ bovine plasma albumin $\mathrm{pH} 7 \cdot 2$. Erythrocytes were collected by heart puncture from day-old chicks hatched out in the laboratory. Rubella haemagglutinin was kindly supplied by Dr C. M. P. Bradstreet, Director, Standards Laboratory, Central Public Health Laboratory, Colindale. A working bromocresol green solution was prepared by adding $2.1 \mathrm{ml}$ of a stock solution ( $7 \mathrm{~g}$ of bromocresol green in 1 litre of $0.02 \mathrm{M}$ sodium hydroxide solution) to $100 \mathrm{ml}$ of citrate buffer $\mathrm{pH} 3 \cdot 8$. Both stock solution and buffer were supplied by Clin. Tech., Ltd.

\section{Methods}

Conventional $0.10 \mathrm{ml}$ of each serum and $0.90 \mathrm{ml}$ of kaolin suspension were added to $3 \times \frac{1}{2}$ in. $(7 \cdot 5 \times$ $1.25 \mathrm{~cm}$ ) test tubes using a 'selectapette' automatic pipette. The tubes were shaken by hand and incu-

Received for publication 15 December 1976 bated at room temperature for 30 minutes. They were then spun at $1800 \mathrm{rpm}$ for 10 minutes in a Mistral $4 \mathrm{~L}$ centrifuge (MSE) and the supernatants decanted into fresh tubes. To each tube $0.02 \mathrm{ml}$ of $20 \%$ chick cell suspension was added. After incubation at $4{ }^{\circ} \mathrm{C}$ for one hour the tubes were centrifuged at $1000 \mathrm{rpm}$ for five minutes. The supernatants (serum dilution 1 in 10) were used to prepare doubling dilutions of from 1 in 10 to 1 in 80 for the HAI test and of 1 in 10 and 1 in 20 for the cell agglutinin control by the microtitre technique described below.

Simplified $0.02 \mathrm{ml}$ of each serum was drawn into the probe of an automatic dispensing apparatus (Compu-pet ${ }^{100}$ ) (Cremer et al., 1975) and discharged with $0.18 \mathrm{ml}$ of $12.5 \%$ kaolin suspension into the first well of the first short row of a new $8 \times 12^{\text {' }} \mathrm{V}$ ' well microtitre plate. The exterior of the probe was then wiped with a paper tissue. The next specimen was added with kaolin to the first well of the following row, the probe wiped, and the procedure repeated until the plate was full (12 specimens). Each completed plate was shaken on a microshaker (Cooke AM 69) for 15 seconds, incubated at room temperature for 15 minutes, and reshaken. The plates were then centrifuged for 15 minutes at $1500 \mathrm{rpm}$ using microtitre plate carriers (Dynatech). To carry out the HAJ screening tests $0.025 \mathrm{ml}$ volumes of supernatant were transferred from the first well of each row to the second, third, sixth, and seventh well using a microtitre dropping pipette. Dilutions up to 1 in 80 for the test and up to 1 in 40 for the serum control were then prepared with a 12-loop automatic microdiluter (Titertek). The procedure is shown in the figure. A $0.025 \mathrm{ml}$ volume of antigen containing four complete units of rubella haemagglutinin was then added to each test well and the same volume of diluent to 


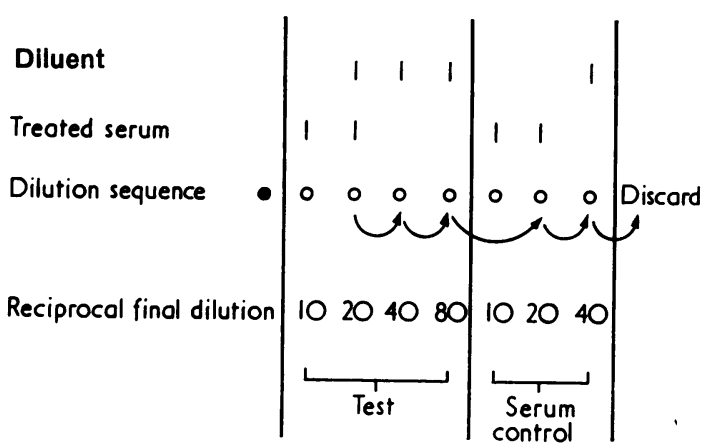

Figure Preparation of serum dilutions.

each control well. After incubation at $4{ }^{\circ} \mathrm{C}$ for one hour $0.025 \mathrm{ml}$ of a $0.25 \%$ suspension of chick cells was added to every well. The plates were held at $4^{\circ} \mathrm{C}$ for one and a half hours and, after a further 15 minutes at room temperature, read over an $x$-ray film illuminator. Patients whose sera had a titre of $\geqslant 20$ were reported as immune to rubella.

The following control sera were tested in triplicate with each batch of tests: (1) a local working standard matched with the British standard for the rubella HAI test, (2) a rubella HAI negative serum, and (3) an aliquot from a serum pool made up to give a titre of between 10 and 20 when examined by our conventional test procedure.

When the simplified method was used a few sera had subsequently to be absorbed to remove chick cell agglutinins. This was done by adding $0.02 \mathrm{ml}$ of $10 \%$ chick cells to the supernatants after the plates had been centrifuged to sediment the kaolin. The plates were agitated for two seconds on the microshaker, incubated for one hour at $4^{\circ} \mathrm{C}$, and recentrifuged for five minutes at $1000 \mathrm{rpm}$.

\section{Results}

EVALUATION OF COMPU-PET ${ }^{100}$

To discover if there was carry-over between specimens sera with titres of $\geqslant 1280$ and $<10$ were tested alternately. In testing 48 sera no instance of carryover of inhibitory activity from a positive into the lowest dilution of the following negative serum was seen. We concluded that the relatively large volume of kaolin suspension used effectively flushed out the probe of the apparatus between specimens.

COMPARISON OF CONVENTIONAL AND SIMPLIFIED METHODS

Two batches, respectively of 150 and 160 sera for screening tests, were examined in parallel by the conventional and simplified methods. Identical results were obtained by the two methods for all but five sera. Four of these had a titre of 40 by one and of $\geqslant 80$ by the other method. The fifth serum had titres of 20 and 40. A further batch of 32 sera from patients in contact with rubella were examined after dilution from 1 in 10 to 1 in 2560 for the HAI test and 1 in 10 and 1 in 20 for the cell agglutinin control. Results obtained by the two methods for these sera did not differ by more than one dilution in any case.

EFFECT OF OMITTING ROUTINE

ABSOR PTION OF CELL AGGLUTININS

In the course of using the simplified method to test eight batches of sera, totalling 1242 specimens, there were seven sera in which the concentration of agglutinins was too high for the HAI titre to be read, and which therefore had to be retested after absorption with chick cells.

\section{Discussion}

The capacity of the wells in a microtitre plate is sufficient to allow in-situ treatment with kaolin suspension of small samples of serum. Up to $0.20 \mathrm{~m}$ of a serum/kaolin mixture can be dispensed into the wells of a new ' $V$ ' plate and shaken without spillage, and this volume may conveniently be delivered by the Compu-pet ${ }^{100}$ apparatus. However, workers who do not have this apparatus may use microtitre dropping pipettes to make up a mixture of $0.025 \mathrm{ml}$ of serum, $0.025 \mathrm{ml}$ of borate buffer, and $0.10 \mathrm{ml}$ of $25 \%$ kaolin suspension in the wells of new or used plates. This mixture yields a serum dilution of about 1 in 5 which can be further diluted and tested as described above.

Chick erythrocytes are commonly used as indicator cells in the rubella HAI test. Titres of chick cell agglutinins in human sera are relatively low, and, provided that the HAI test includes control dilutions of each serum up to 1 in 40 , we have found that less than $1 \%$ of specimens need to be retested with preliminary red cell absorption. We have therefore felt justified in omitting the routine absorption of agglutinins from our simplified procedure.

Two sources of error may be encountered in the simplified procedure: firstly a failure to pick up serum from the specimen bottle with the probe of the Compu-pet ${ }^{100}$ and, secondly, a failure to transfer the treated serum from the first well of each row. These omissions may be recognised by the following means. When the serum dilutions have been prepared the plates are held at eye level and the volume of supernatant remaining in the first well of each row is checked. At the end of the test the presence of serum in these wells is verified by adding a drop of the working bromocresol green solution. If serum is 
present a green-blue colour develops within 30 seconds. If the wells hold only kaolin the suspension remains yellow.

The cost of adopting this simplified rubella HAI test need not be great. The Compu-pet ${ }^{100}$ apparatus is complex and expensive (about $£ 800$ ) but is not essential to the procedure. The microtitre plate carriers, which are made to fit most of the centrifuge heads in common use, cost less than $£ 30$ a pair. The microshaker costs $£ 90$ (November 1976 prices).

The simplified method halves the labour of carrying out a large batch of rubella HAI tests. It also has the advantage that specimen numbers can be marked on the plates and sera dispensed directly into them. In this way large numbers of specimens can be handled without their falling out of order, as may happen during the manipulations of con- ventional HAI procedures. We therefore recommend this method, particularly for large scale antenatal rubella screening and for epidemiological inquiries in which only small volumes of serum may be available.

We thank Dr Brenda Slavin and Miss Patricia Bennett, who suggested the use of bromocresol green to detect the presence of serum, and Drs D. A. McSwiggan and Marguerite S. Pereira who read the manuscript.

\section{References}

Cremer, A. W., Mellars, B., and Stokes, E. Joan (1975). The Compu-pet 100: a versatile dispenser-diluter for the mechanization of microbiological techniques. Journal of Clinical Pathology, 28, 37-41. 